\title{
GENOME-WIDE AND MIa LOCUS-SPECIFIC CHARACTERISATION OF LATVIAN BARLEY VARIETIES
}

\author{
Agnese Kokina and Nils Rostoks \\ Faculty of Biology, University of Latvia, Kronvalda bulv. 4, Rīga, LV-1586, LATVIA
}

Communicated by İzaks Rašals

\begin{abstract}
Genetic diversity in locally adapted germplasm forms the basis for crop improvement through breeding. While single loci have been routinely used for studies of genetic diversity, the highthroughput genotyping platforms that have recently become available for large genome crop plants offer an unbiased view on genetic diversity on a genome-wide scale. We assessed genetic diversity in Latvian barley varieties and some progenitors using DArT markers and studied the extent of linkage disequilibrium in Latvian germplasm. Further, genetic diversity at three loci flanking the barley powdery mildew Mla locus conferring race-specific resistance was studied in Latvian barley germplasm. The Mla locus encompasses several closely related resistance gene homologues with a complex evolutionary history, which complicates the design of molecular markers for different Mla genes. We observed significant linkage disequilibrium between the single nucleotide polymorphisms (SNPS) at the three loci, 206i20_T7, ABC15612, and 538P8, flanking the Mla locus. SNP haplotypes were largely in agreement with known phenotypic data and, thus, may be potentially diagnostic for Mla resistance genes in hybrids.
\end{abstract}

Key words: barley, Mla powdery mildew resistance, DArT, sequence haplotype.

\section{INTRODUCTION}

Genetic diversity provides the material for natural selection and ensures that species as a whole survives changing environmental conditions (von Bothmer et al., 2003). In domesticated crop plants genetic diversity provides material for plant breeders to develop new varieties with novel uses or better adaptation to local environment. Knowledge of genetic diversity at a genome-wide level and at specific loci responsible for the key traits is essential for crop improvement.

Genetic diversity is significantly reduced in domesticated crop plants compared to their wild relatives (Tanksley and McCouch, 1997). Studies of barley have found significant reduction of genetic diversity in modern cultivars compared to wild barley accessions and landraces (Russell et al., 2004) traditionally explained by a "founder" effect. Further reduction of diversity may have occurred during the transition to modern breeding, when only a limited number of genotypes was used for development of modern varieties, although this may be in part compensated by introgression of specific traits from wild relatives and landraces. For example, even though most of the European cultivars bred in the 20th century have a narrow germplasm basis due to a small number of founder varieties (Fischbeck, 1992), there appears to be little reduction in genetic diversity in the case of Baltic and Nordic barleys or even an increase in allele diversity in modern varieties compared to those bred in the middle of the 20th century (Kolodinska-Brantestam et al., 2004; Kolodinska-Brantestam et al., 2007).

Genome-wide diversity studies allow to characterise the overall diversity of germplasm, as well as to establish relatedness of certain genotypes. They can also be used to roughly identify genome regions subjected to selective sweeps during the domestication and breeding (Rostoks et al., 2006). Genetic markers distributed across genomes are used for linkage and quantitative trait loci (QTL) mapping. Various high-throughput genotyping technologies are available for whole-genome analysis of crop plants. Recently a high-throughput single nucleotide polymorphism (SNP) genotyping platform based on Illumina GoldenGate technology was developed for barley that allowed to study genetic diversity in ca. 100 European barley varieties using over 1000 SNPs (Rostoks et al., 2006). Alternatively, there are genotyping platforms that do not require prior knowledge of gene sequences, such as DArT (Jaccoud et al., 2001). DArT platform has been used extensively in barley both for studies of genetic diversity and for linkage mapping (Wenzl et al., 2004). Most of the barley DArT markers are mapped on a consensus map including RFLP and SSR loci, making DArT platform useful for diversity studies (Wenzl et al., 2006).

Powdery mildew is an economically important barley disease, caused by a fungal pathogen Blumeria (Erysiphe) graminis f.sp. hordei. While the pathogen is relatively eas- 
ily controlled by fungicides, it may represent a serious threat for barley produced in low input and organic agriculture. Alternatively, disease can be controlled using resistance genes that are either specific for certain fungal pathotypes or confer resistance to a broad range of pathotypes. The complex, race specific powdery mildew resistance Mla locus is located on the short arm of barley chromosome $5(1 \mathrm{H})$ and consists of several NBS-LRR type disease resistance genes providing resistance to different fungal pathotypes (Wei et al., 1999). The locus has been completely sequenced from the susceptible cultivar Morex and resistance genes Mlal (Zhou et al., 2001), Mla6 (Halterman et al., 2001), Mla12 (Shen et al., 2003) and Mlal3 (Halterman et al., 2003) have been characterised (Mejlhede et al., 2006). Because of the close sequence homology of different Mla genes, it is complicated to design molecular markers for specific Mla genes. However, because modern barley varieties have originated from a limited germplasm pool relatively recently (Fischbeck, 1992), it is reasonable to expect that linkage disequilibrium across the Mla locus is maintained. Thus, sequence analysis of closely linked loci could be used both to assess the sequence diversity at the Mla locus and to predict the disease resistance specificity of the Mla locus. There are over 30 known Mla alleles, but only a few of them are extensively used in European barley breeding (Weibull et al., 2003). Transfer of novel Mla genes into adapted germplasm necessitates development of efficient tools for introgression, which is essential since the pathogen evolves virulence against the currently used disease resistance genes.

In this study we used genome-wide DArT genotyping to assess genetic diversity in Latvian barley varieties and some progenitors. Further, we characterised DNA sequence diversity at the race-specific disease resistance locus Mla in locally adapted Latvian barley varieties.

\section{MATERIALS AND METHODS}

\section{Plant material and DNA extractions}

DNA from the 23 Latvian barley varieties (Table 1) was extracted from single barley plants using a modified procedure (Edwards et al., 1991). Plant tissue was collected either from a field-grown plant or a seedling germinated on Petri dish in the laboratory. Seeds were obtained from the State Priekuli Plant Breeding Institute and the State Stende Cereal Breeding Institute. Seeds of European barley varieties were obtained from the IPK Gene Bank and the Nordic Gene Bank.

\section{DArT genotyping}

DArT genotyping of the 23 Latvian varieties (Table 1) and some other barley varieties (44 in total) was carried out by Triticarte Pty Ltd (North Ryde, NSW, Australia). DArT genotyping yielded 1180 markers in the set of 44 barley lines which were analysed as described by Jaccoud et al. (2001) and Wenzl et al. (2004).
Table 1

CLASSIFICATION OF LATVIAN BARLEY VARIETIES IN HAPLOTYPES BASED ON SEQUENCE POLYMORPHISMS AT 2006i20_T7, ABC15612 and 538P8 loci.

\begin{tabular}{|c|c|c|}
\hline Variety & Sequence haplotype & Mla resistance ${ }^{1}$ \\
\hline Abava & $\mathrm{H} 1$ & Mla 8 \\
\hline Imula & $\mathrm{H} 1$ & Mla 8 \\
\hline Klinta & $\mathrm{H} 1$ & Mla6+Mla 8 \\
\hline Kombainieris & $\mathrm{H} 1$ & Mlas \\
\hline Priekuḷu 60 & $\mathrm{H} 1$ & Mlas \\
\hline Rūja & $\mathrm{H} 1$ & Mla 8 \\
\hline Agra & $\mathrm{H} 2$ & Mla9 \\
\hline Ansis & $\mathrm{H} 3$ & mla \\
\hline Balga & $\mathrm{H} 3$ & $m l a$ \\
\hline Ilga & $\mathrm{H} 3$ & Mla 8 \\
\hline Linga & $\mathrm{H} 3$ & $m l a$ \\
\hline Druvis & $\mathrm{H} 4$ & Mla $8+$ Mla 12 \\
\hline Dzintars & H5 & Mla? \\
\hline Gāte & H6 & Mla7 \\
\hline Idumeja & $\mathrm{H} 7$ & Mla9 \\
\hline Kristaps & $\mathrm{H} 8$ & Mla7 \\
\hline Rasa & $\mathrm{H} 8$ & Mla7 \\
\hline Latvijas vietējie & H9 & Mla 8 \\
\hline Malva & $\mathrm{H} 10$ & Mla $8+$ Mla13 \\
\hline Sencis & $\mathrm{H} 10$ & Mla13 \\
\hline Priekuḷu 1 & H11 & Mla 8 \\
\hline Stendes & $\mathrm{H} 12$ & Mla 8 \\
\hline Vairogs & H13 & Mla 8 \\
\hline
\end{tabular}

${ }^{1}$ Mla resistance according to Dreiseitl and Rashal (2004); Tueryapina et al. (1996).

\section{PCR and sequence analysis of the Mla flanking loci}

Primer sequences for 206i20_T7 locus are described (Wei et al., 1999). Primer sequences for the ABC15612 and 538P8 loci flanking the Mla locus were obtained from Dr. Luke Ramsay (SCRI, Dundee, Scotland, UK). PCR was performed in $20 \mathrm{ml}$ reactions consisting of ca. $50 \mathrm{ng}$ DNA, $10 \mu \mathrm{M}$ primers, $1 \times$ reaction buffer (Fermentas, Vilnius, Lithuania), $2.5 \mathrm{mM} \mathrm{MgCl} 2,0.2 \mathrm{mM}$ dNTPs and $1 \mathrm{u}$ of Hot Start Taq polymerase (Fermentas, Vilnius, Lithuania). Sequencing was done with the same primers as PCR using BigDye 3.1. terminator mix (Applied Biosystems, Foster City, CA, USA) on an ABI3730 sequencer according to the manufacturer's recommendations.

\section{Data analysis}

Quality control of DArT genotype data identified 326 loci with $\mathrm{Q}$ value over 80 and no missing genotype data in the set of 44 varieties. Principal Coordinate Analysis (PCoA) of the DArT genotype data was performed with DARwin5 software (http://darwin.cirad.fr/darwin) using the Manhattan dissimilarity index. A UPGMA dendrogram of the DArT genotype data was constructed using distances derived by restdist software from the Phylip package using a modified 


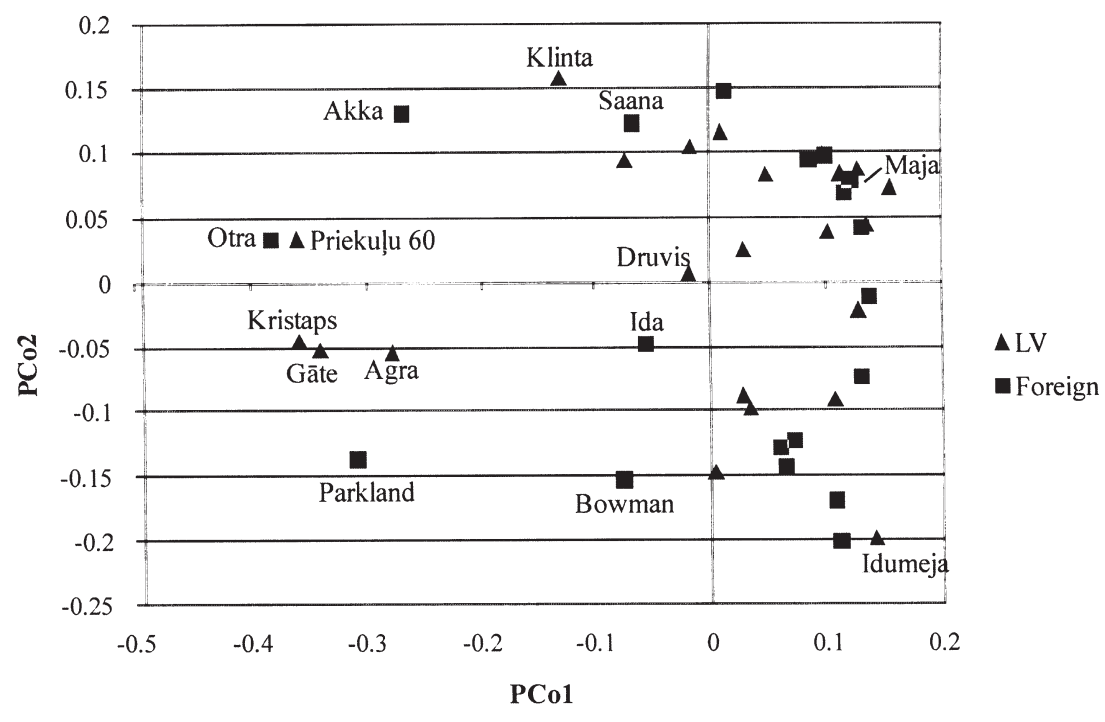

Fig. 1. Principal Coordinate Analysis (PCoA) of DArT genotype data performed with DARwin5. PCoA is based on data from 44 varieties and 326 loci. PCo1 and PCo2 explain $30.9 \%$ and $12.9 \%$ variation in genotype data, respectively. neighbour joining algorithm (Felsenstein, 1989). Extent of linkage disequilibrium in the 23 Latvian barley varieties was calculated from genotypes at 465 loci, selected based on the following criteria: a) minor allele frequency $(\mathrm{MAF})>0.1$ in the set of 23 varieties; b) not more than two missing genotypes per locus; c) known and unambiguous map location on barley consensus map (Wenzl et al., 2006). Tassel (Bradbury et al., 2007) was used to calculate pairwise LD (R2) between all 465 loci.

Base calling and sequence assembly of the Mla flanking loci was conducted using the Staden software package (Staden, 1996). Sequence alignments were identified with Clustal 1.83 software (Thompson et al., 1997) and then used to calculate nucleotide diversity at each locus using DNASP 4.20 (Rozas et al., 2003). SNP information extracted from sequence alignments was used to calculate haplotype number and haplotype diversity at each locus using DNASP. The sequence haplotype distance matrix based on 206i20_T7, ABC15612 and 538P8 loci and neighbour programme from the Phylip package (Felsenstein, 1989) were used to construct the UPGMA (Unweighted Pair Group Method with Arithmetic Means) dendrogram. Extent of LD $\left(\mathrm{R}^{2}\right)$ across the three loci was calculated using Tassel (Bradbury et al., 2007) based on 17 SNPs with MAF > 0.1 from 23 Latvian barley varieties.

\section{RESULTS}

\section{Genetic diversity and population structure in Latvian barley based on DArT genotype data}

Twenty-three Latvian barley varieties, as well as some progenitors and several other European barley accessions were genotyped using the barley DArT genotyping platform (Wenzl et al., 2004). Of the 1180 loci, 326 were selected with quality (Q) value over 80 and had no missing data among the 44 barley accessions. The average polymorphism information content (PIC) value of selected DArT markers in this germplasm set was 0.36. Principal Coordinate Analysis was used to study the partitioning of the germ- plasm (Fig. 1). There was no obvious differentiation between Latvian varieties and the rest of European germplasm; however, the germplasm was strongly partitioned along the PCo1.

The UPGMA dendrogram constructed from the genotype data to study the relationships among Latvian and other European germplasm (Fig. 2) showed that the two North American varieties, 'Parkland' and 'Bowman', clustered separately, while the European and Latvian varieties formed two distinct groups.

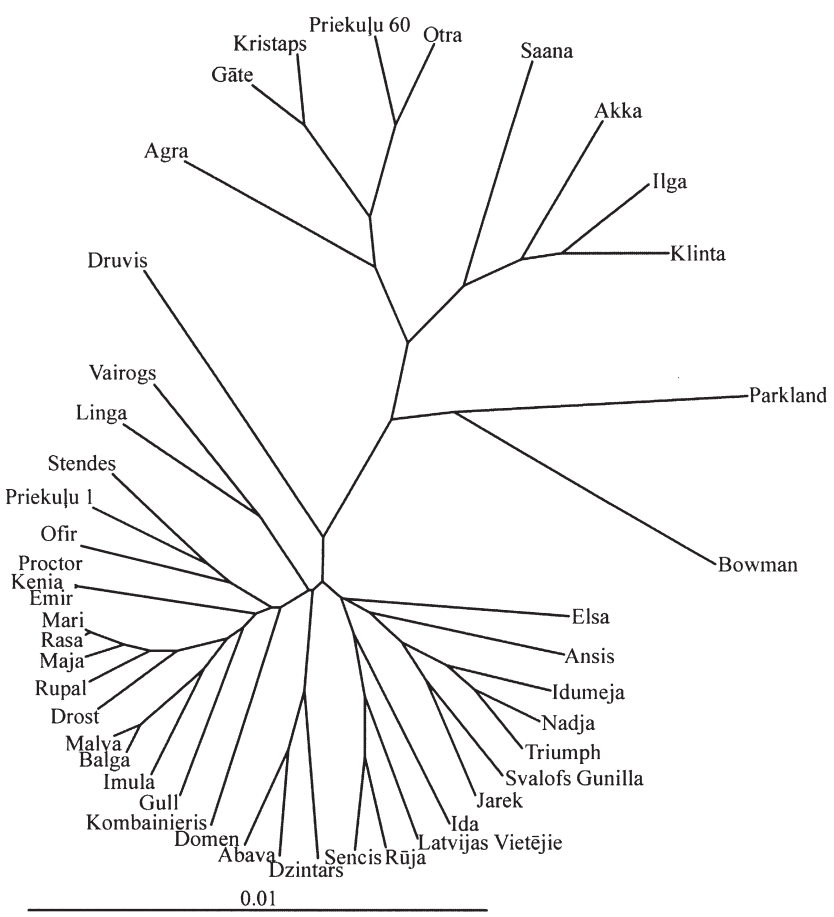

Fig. 2. Unrooted UPGMA dendrogram of DArT genotypes based on data from 44 varieties and 326 loci. The distance matrix was derived using fragment option in the Restdist programme from the Phylip package using modified Nei distances (Felsenstein, 1989). The dendrogram was constructed using the UPGMA option in the Neighbour programme. 


\section{Genome-wide linkage disequilibrium in Latvian barley}

Genome-wide linkage disequilibrium was studied in the set of 23 Latvian barley varieties using a selection of DArT genotype data. Since the location of the DArT loci on the barley consensus map is known (Wenzl et al., 2006), the pairwise LD between all loci could be plotted against the genetic distance between the loci (Fig. 3). Extensive LD could be observed for loci as far as $100 \mathrm{cM}$, suggesting some population substructure in the germplasm. Extent of LD between the markers along the barley chromosome $1 \mathrm{H}$ carrying the Mla locus was also studied (Fig. 5A). Significant LD could be observed for subtelomeric markers on the short arm of chromosome $1 \mathrm{H}$, where the Mla locus is located, as well as in the centromeric regions.

\section{Sequence, haplotype and linkage disequilibrium analysis of the Mla locus in Latvian barley varieties}

The three loci, 206i20_T7, ABC15612 and 538P8, flanking the Mla region (Fig. 4A) on barley chromosome 5(1H) were amplified and sequenced from 23 Latvian barley varieties. Sequences have been submitted to the National Centre for Biotechnology Information GenBank as population data sets (Accessions EU934103-EU934223). Sequences were used to identify 49 SNP and several indel polymorphisms among Latvian barley varieties (data not shown). SNPs were used to group sequences into thirteen haplotypes across both loci and those, in turn, were used to construct a UPGMA dendrogram (Figure 4B, Table 1). In order to assess extent of LD across the Mla locus, SNP information from the loci 206i20_T7, ABC15612 and 538P8 was used (Fig. 5B). As expected significant LD was observed at all three loci, but several SNPs exhibited high and statistically significant LD across the Mla locus, indicating that allelic states at the flanking loci might be associated with the Mla resistance gene.

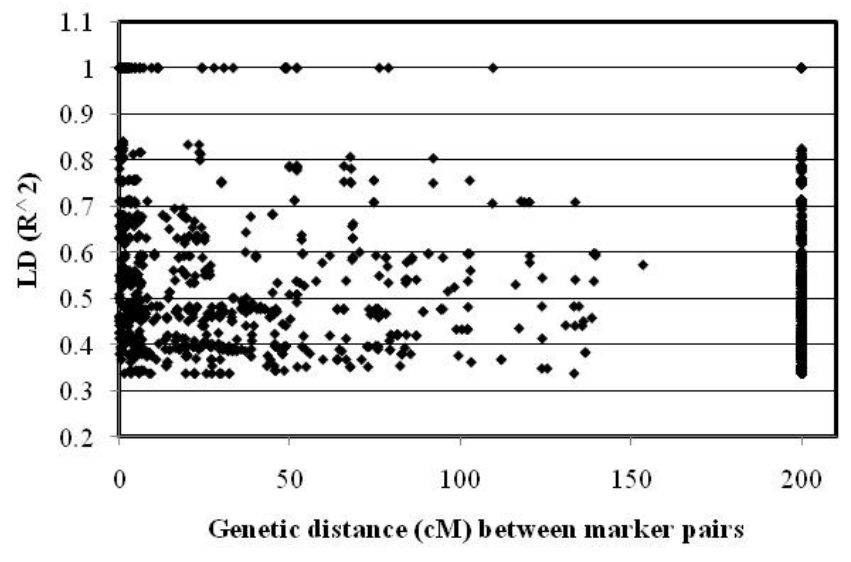

Fig. 3. Extent of linkage disequilibrium in Latvian barley varieties based on whole-genome DArT marker data. Linkage disequilibrium $\left(\mathrm{R}^{2}\right)$ values are plotted against genetic distance $(\mathrm{cM})$ between marker pairs. Pairwise LD was calculated between 465 marker loci using Tassel (Bradbury et al., 2007) as described in Materials and Methods. Only statistically significant $(P<0.01)$ associations are shown. LD values between loci on different chromosomes are plotted at a fixed distance of $200 \mathrm{cM}$.

\section{DISCUSSION}

Based on DArT genotype data, the two North American varieties, 'Parkland' and 'Bowman', clustered separately, while the European germplasm including Latvian varieties was partitioned into two clusters. Three varieties, 'Emir', 'Kenia' and 'Proctor', clustered together and the genotype data of these varieties appeared to be identical. Similarly, varieties 'Mari' and 'Rasa' differed only at three DArT loci. Because these are well known as distinct varieties, it is possible that seed, tissue or DNA mix-up has occurred. Data from these varieties were not used in subsequent analysis.

While presently there is no obvious explanation for the partitioning of the germplasm (excluding North American varieties) into two groups, there are several apparent agree-

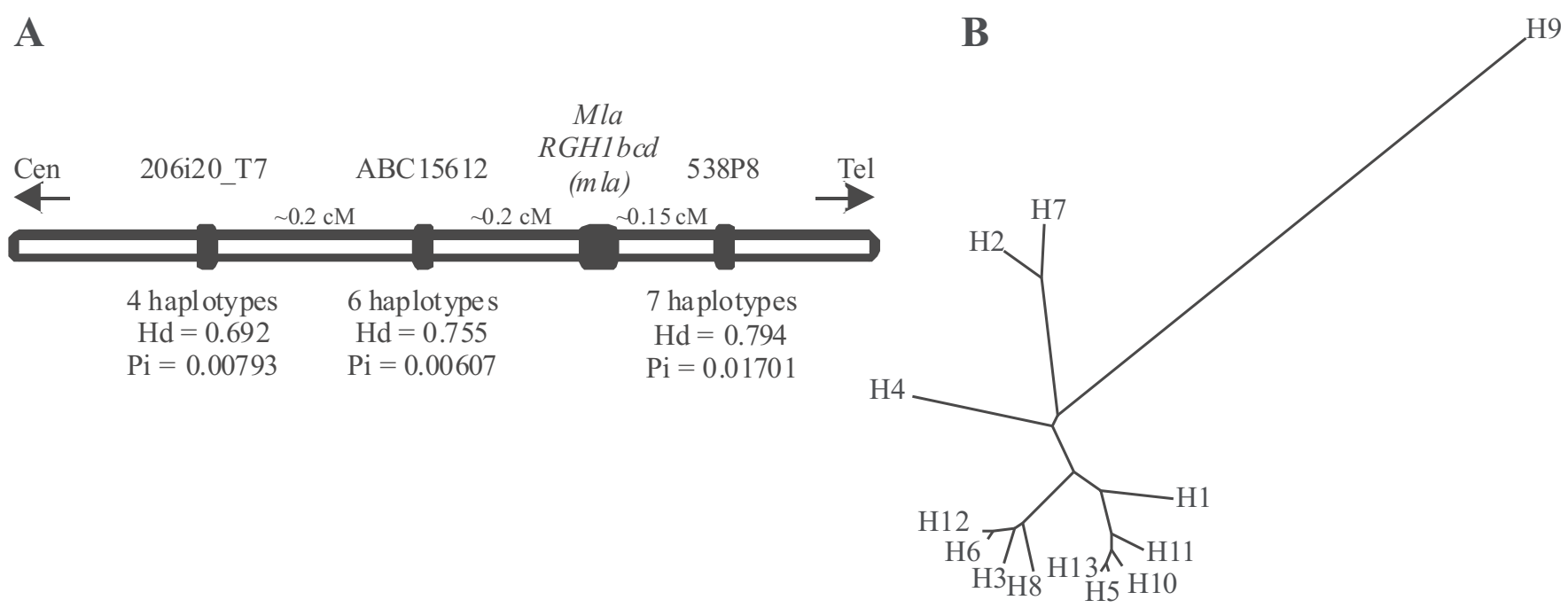

Fig. 4. Structure and sequence analyses of the Mla locus in Latvian barley varieties. A. Structure of the Mla locus on chromosome $1 \mathrm{H}$ with molecular marker loci, 2006i20_T7, ABC15612 and 538P8 is indicated (Wei et al., 1999). Sequence haplotype number, haplotype diversity and nucleotide diversity at each locus are indicated below. Cen - direction towards centromere; Tel - direction towards telomere. B. UPGMA dendrogram of the sequence haplotypes formed by combination of all three loci. For varieties in haplotypes see Table 1. Branch length indicates nucleotide substitutions per site. 
A

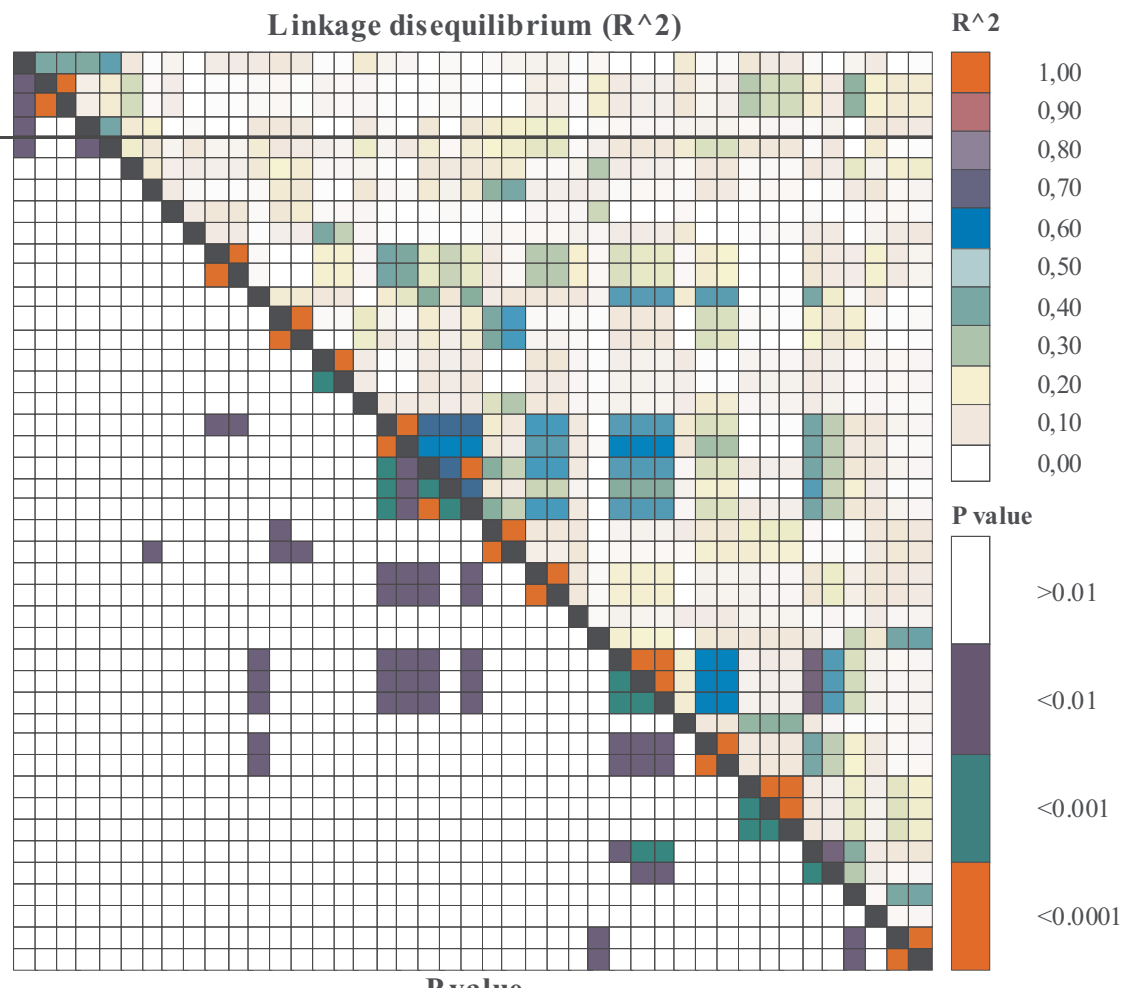

B

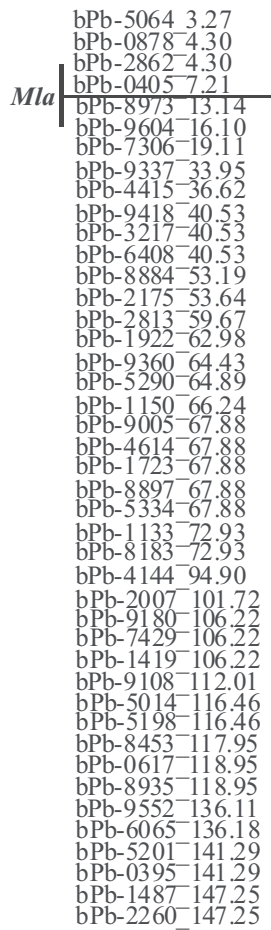

Linkage dis equilibrium $\left(\mathrm{R}^{\wedge} 2\right)$

$\mathbf{R}^{\wedge} \mathbf{2}$

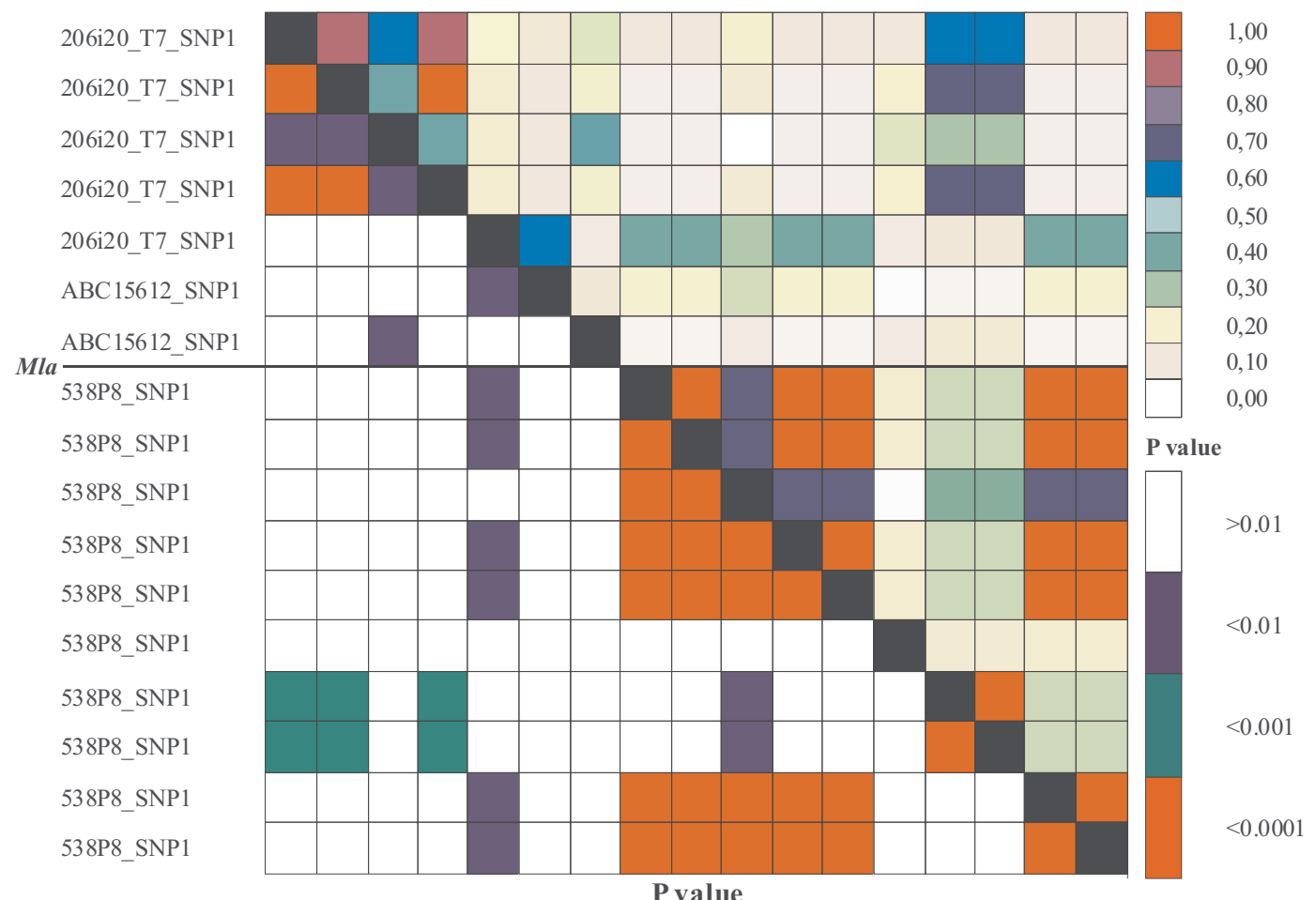

Pvalue

Fig. 5. Linkage disequilibrium in the Latvian barley genome. A. Linkage disequilibrium along the barley chromosome $1 \mathrm{H}$ based on DArT marker data. B. Linkage disequilibrium of the SNP loci flanking the barley Mla locus. Upper triangle depicts LD between individual DArT or SNPs markers measured as $R^{2}$. Lower triangle depicts $P$ values of the $L D$. Correspondence of $R^{2}$ and $P$ values and colours is shown on the right. Only the DArT and SNP markers with minor allele frequency (MAF) over 0.1 were analysed. LD and the corresponding P values were calculated in TASSEL (Bradbury et al., 2007). Location of the Mla locus on the chromosome 1H (Wenzl et al., 2006) and between flanking SNP loci is shown on the left. DArT loci names in panel A include position on linkage map in centimorgans. SNP names in panel B include position in alignment as in population data sets in GenBank.

ments with known pedigrees, e.g., 'Otra' and 'Agra' are clustered together ('Agra' is 'Priekul,u 1' $\mathrm{x}$ 'Otra') and 'Abava' and 'Domen' are grouped together ('Abava' is from a cross involving 'Mari', 'Elsa' and 'Domen'). All the varieties included in the analysis had a spring growth habit and most of them were two-row, with the exception of 'Agra', 'Druvis', 'Priekuḷ 1', 'Vairogs', 'Dzintars', 'Parkland' and 'Otra'. These major phenotypic traits often 
differentiate the germplasm because of breeding traditions (Fischbeck, 1992). Rostoks et al. (2006) observed strong population structure based on spring or winter growth habit in European barley germplasm using genome-wide SNP genotyping. PCo analysis of DArT genotypes revealed strong partitioning along the PCo1 axis, which may be partially explained by the presence of several six-row varieties in the germplasm set. Further studies involving comparison of agronomic qualities and pedigrees will be needed to explain the partitioning observed in the DArT dendrogram (Fig. 2).

DArT genotype data was used to analyse the extent of LD in the genome of Latvian barley varieties. In outbreeding plant species, such as maize, the LD usually breaks down within several hundreds of base pairs (Flint-Garcia et al., 2003), while in inbreeding crops, such as barley and wheat, the LD is expected to be more extensive. The extent of LD in cultivated European barley was reported to be at least $200 \mathrm{kbp}$ based on sequence analysis of four loci spanning barley hardness locus, while it decayed much more rapidly in wild barley and landraces (Caldwell et al., 2006). Genome-wide analysis of barley SNPs indicated that pairwise LD can extend up to $10 \mathrm{cM}$ (Rostoks et al., 2006). Population structure can significantly affect the extent of observed LD and, as a result, can confound association mapping studies, if subpopulations differ both in SNP allele frequency and trait prevalence (Wang et al., 2005). The current study showed LD extending between markers located as far as $100 \mathrm{cM}$ apart, indicating population stratification, although the small sample size (23 varieties) might also affect the results.

The Mla locus has been completely sequenced from the susceptible variety 'Morex' (Wei et al., 2002), and several Mla genes that provide race-specific mildew resistance have been isolated. Complexity of the locus, high homology between Mla genes and putative paralogues elsewhere in the barley genome (Mejlhede et al., 2006) so far have prevented design of molecular markers for different Mla resistance genes. Linkage disequilibrium (non-random association of alleles) in cultivated spring barley was recently reported to extend to centimorgan distances (Caldwell et al., 2006; Rostoks et al., 2006). Therefore, the allelic state of the loci flanking Mla genes could be used to predict the resistance specificity at the Mla locus, if no recombination between the flanking loci and Mla locus had occurred. European cultivated barley germplasm on average exhibited relatively low nucleotide and haplotypes diversity per locus (Rostoks et al., 2005; 2006). In contrast, a high number of sequence haplotypes was observed at the Mla flanking loci among the 23 Latvian varieties perhaps indicating that wider germplasm was used for breeding Latvian barley. Nevertheless, several SNPs flanking the Mla locus were in strong LD (Fig. 5B) indicating that little recombination has occurred within the region. Sequence haplotypes were compared to published mildew resistance specificities of Latvian barley varieties (Tueryapina et al., 1996; Dreiseitl and Rashal, 2004) (Table 1). 'Latvijas Vietējie', a Latvian landrace, ap- peared to be very distant to other Latvian varieties, however, this was centered by high polymorphism at the ABC15612 locus, while at the 538P8 locus it was identical to 'Abava', 'Imula', 'Klinta', 'Kombainieris', 'Rūja' and 'Priekulu 60'. In general, good agreement was found between sequence haplotype data and experimentally determined Mla resistance genes in Latvian barley varieties (Tueryapina et al., 1996; Dreiseitl and Rashal, 2004) (Table 1), while the existing discrepancies could be explained by differences in methodology. We sequenced marker loci from a single plant for each variety, but mildew resistance tests were carried out on pools of plants (Dreiseitl and Rashal, 2004). The same study identified the majority of Latvian barley cultivars as heterogeneous with respect to Mla resistance genes. Similar heterogeneity has also been observed with molecular markers (Kolodinska-Brantestam, personal communication). For example, the variety 'Malva' which was identified as carrying Mla 8 and Mlal3 resistance genes, in sequence analysis clustered together with 'Sencis' (Mla13) probably indicating that the individual plant under study was Mla13 resistant. In addition, the Mla 8 allele has been reported as very difficult to phenotype, because only a few pathogen isolates have a compatible avirulence gene (Jensen 1995). Thus, the varieties identified as Mla8 may in fact possess a different sequence allele. Overall, the agreement was good and we are currently working on extending sequence analysis to some mildew resistance donors with a goal to establish molecular markers that can be used to pyramid mildew resistance genes.

\section{ACKNOWLEDGEMENTS}

The study was funded by the Latvian National Programme in Agrobiotechnology, the Latvian Council of Science project 07.2055 and University of Latvia grant ZP-59. Seeds of European barley varieties were obtained from the IPK Gene Bank and the Nordic Gene Bank. The State Priekul,i Plant Breeding Institute and the State Stende Cereal Breeding Institute provided seeds and plant material for DNA extractions. DNA extractions were performed by Bruno Opermanis. Discussions with Drs. L. Ramsay, I. Rashal and A. Kolodinska-Brantestam are gratefully acknowledged.

\section{REFERENCES}

Bradbury, P.J., Zhang, Z., Kroon, D.E., Casstevens, T.M., Ramdoss, Y., Buckler, E.S. (2007). TASSEL: Software for association mapping of complex traits in diverse samples. Bioinformatics, 23, 2633-2635.

Caldwell, K.S., Russell, J.R., Langridge, P., Powell, W. (2006). Extreme population dependent linkage disequilibrium detected in an inbreeding plant species, Hordeum vulgare. Genetics, 172, 557-567.

Dreiseitl, A., Rashal, I. (2004). Powdery mildew resistance genes in Latvian barley varieties. Euphytica, 135, 325-332.

Edwards, K., Johnstone, C., Thompson, C. (1991). A simple and rapid method for the preparation of plant genomic DNA for PCR analysis. $\mathrm{Nu}$ cleic Acids Res., 19, 1349.

Felsenstein, J. (1989). PHYLIP - Phylogeny Inference Package (Version 3.2). Cladistics, 5, 164-166. 
Fischbeck, G. (1992). Barley cultivar development in Europe-success in the past and possible changes in the future. In Munck, L. (ed.), Barley Genetics VI. Proceedings of the 6th International Barley Genetics Symposium (pp. 885-901). Helsinborg: Munksgaard International Publishers.

Flint-Garcia, S.A., Thornsberry, J.M., Buckler, E.S. (2003). Structure of linkage disequilibrium in plants. Annu. Rev. Plant Biol., 54, 357-374.

Halterman, D., Zhou, F., Wei, F., Wise, R., Schulze-Lefert, P. (2001). The MLA6 coiled-coil, NBS-LRR protein confers AvrMla6-dependent resistance specificity to Blumeria graminis f. sp. hordei in barley and wheat. Plant J., 25, 335-348.

Halterman, D.A., Wei, F., Wise, R.P. (2003). Powdery mildew-induced Mla mRNAs are alternatively spliced and contain multiple upstream open reading frames. Plant Physiol., 131, 558-567.

Jaccoud, D., Peng, K., Feinstein, D., Kilian, A. (2001). Diversity arrays: A solid state technology for sequence information independent genotyping. Nucleic Acids Res., 29, E25.

Jensen, H. (1995). Presence of barley powdery mildew resistance gene Mla 8 in some 'Pallas' near-isogenic barley lines. Barley Gen. Newslett., 24, $71-74$.

Kolodinska-Brantestam, A., von Bothmer, R., Dayteg, C., Rashal, I., Tuvesson, S., Weibull, J. (2007). Genetic diversity changes and relationships in spring barley (Hordeum vulgare L.) germplasm of Nordic and Baltic areas as shown by SSR markers. Genet. Res. Crop Evol., 54, 749-758.

Kolodinska-Brantestam, A., von Bothmer, R., Dayteg, C., Rashal, I., Tuvesson, S., Weibull, J. (2004). Inter simple sequence repeat analysis of genetic diversity and relationships in cultivated barley of Nordic and Baltic origin. Hereditas, 141, 186-192.

Mejlhede, N., Kyjovska, Z., Backes, G., Burhenne, K., Rasmussen, S.K., Jahoor, A. (2006). EcoTILLING for the identification of allelic variation in the powdery mildew resistance genes mlo and Mla of barley. Plant Breeding, 125, 461-467.

Rostoks, N., Mudie, S., Cardle, L., Russell, J., Ramsay, L., Booth, A., Svensson, J.T., Wanamaker, S.I., Walia, H., Rodriguez, E.M., Hedley, P.E., Liu, H., Morris, J., Close, T.J., Marshall, D.F., Waugh, R. (2005). Genome-wide SNP discovery and linkage analysis in barley based on genes responsive to abiotic stress. Mol. Genet. Genomics, 274, 515-527.

Rostoks, N., Ramsay, L., MacKenzie, K., Cardle, L., Bhat, P.R., Roose, M.L., Svensson, J.T., Stein, N., Varshney, R.K., Marshall, D.F., Graner, A., Close, T.J., Waugh, R. (2006). Recent history of artificial outcrossing facilitates whole-genome association mapping in elite inbred crop varieties. Proc. Natl. Acad. Sci. U S A, 103, 18656-18661.

Rozas, J., Sanchez-DelBarrio, J.C., Messeguer, X., Rozas, R. (2003). DnaSP, DNA polymorphism analyses by the coalescent and other methods. Bioinformatics, 19, 2496-2497.

Russell, J., Booth, A., Fuller, J., Harrower, B., Hedley, P., Machray, G., Powell, W. (2004). A comparison of sequence-based polymorphism and haplotype content in transcribed and anonymous regions of the barley genome. Genome, 47, 389-398.
Shen, Q.H., Zhou, F., Bieri, S., Haizel, T., Shirasu, K., Schulze-Lefert, P. (2003). Recognition specificity and RAR1/SGT1 dependence in barley Mla disease resistance genes to the powdery mildew fungus. Plant Cell, 15, $732-744$.

Staden, R. (1996). The Staden sequence analysis package. Mol. Biotechnol., 5, 233-241.

Tanksley, S.D., McCouch, S.R. (1997). Seed banks and molecular maps: Unlocking genetic potential from the wild. Science, 277, 1063-1066.

Thompson, J.D., Gibson, T.J., Plewniak, F., Jeanmougin, F., Higgins, D.G (1997). The CLUSTAL_X windows interface: Flexible strategies for multiple sequence alignment aided by quality analysis tools. Nucleic Acids Res., 25, 4876-4882.

Tueryapina, R., Jensen, H., Rashal, I. (1996). Powdery mildew resistance genes in Baltic spring barley varieties and breeding lines. Barley Genetics Newsletter, 27, 18-21.

von Bothmer, R., Sato, K., Knuepffer, H., van Hintum, T. (2003). Barley diversity - an introduction. In von Bothmer, R., van Hintum, T., Knuepffer, H., Sato, K. (eds.). Diversity in barley (Hordeum vulgare L.) (pp. 3-8). Amsterdam: Elsevier Science.

Wang, W.Y., Barratt, B.J., Clayton, D.G., Todd, J.A. (2005). Genome-wide association studies: Theoretical and practical concerns. Nat. Rev. Genet., 6 , 109-118.

Wei, F., Wing, R.A., Wise, R. (2002). Genome dynamics and evolution of the Mla (powdery mildew) resistance locus in barley. Plant Cell, 14, 1903-1917.

Wei, F., Gobelman-Werner, K., Morroll, S.M., Kurth, J., Mao, L., Wing, R., Leister, D., Schulze-Lefert, P., Wise, R.P. (1999). The Mla (powdery mildew) resistance cluster is associated with three NBS-LRR gene families and suppressed recombination within a $240-\mathrm{kb}$ DNA interval on chromosome 5S (1HS) of barley. Genetics, 153, 1929-1948.

Weibull, J., Walther, U., Sato, K., Habekuss, A., Kopahnke, D., Proeseler, G. (2003). Diversity in resistance to biotic stresses. In von Bothmer, R., van Hintum, T., Knuepffer, H., Sato, K. (eds.). Diversity in barley (Hordeum vulgare L.) (pp. 143-178). Amsterdam: Elsevier Science.

Wenzl, P., Li, H., Carling, J., Zhou, M., Raman, H., Edie, E., Hearnden, P., Maier, C., Xia, L., Caig, V., Ovesna, J., Cakir, M., Poulsen, D., Wang, J., Raman, R., Smith, K.P., Muehlbauer, G.J., Chalmers, K.J., Kleinhofs, A., Huttner, E., Kilian, A. (2006). A high-density consensus map of barley linking DArT markers to SSR, RFLP and STS loci and agricultural traits. BMC. Genomics, 7, 206.

Wenzl, P., Carling, J., Kudrna, D., Jaccoud, D., Huttner, E., Kleinhofs, A., Kilian, A. (2004). Diversity Arrays Technology (DArT) for whole-genome profiling of barley. Proc. Natl. Acad. Sci. U S A, 101, 9915-9920.

Zhou, F., Kurth, J., Wei, F., Elliott, C., Vale, G., Yahiaoui, N., Keller, B., Somerville, S., Wise, R., Schulze-Lefert, P. (2001). Cell-autonomous expression of barley Mlal confers race-specific resistance to the powdery mildew fungus via a Rarl-independent signaling pathway. Plant Cell, 13, 337-350.

Received 30 July 2008

\section{LATVIJAS MIEŽU ŠKIRNU GENOMA UN Mla LOKUSA RAKSTUROJUMS}

Ģenētiskā daudzveidība lokāli adaptētā lauksaimniecības augu materiālā veido pamatu selekcijai un jaunu škirņu veidošanai. Ģenētiskās daudzveidības pētījumos bieži lieto atsevišķu genoma lokusu vai gēnu sekvences analīzi, taču aizvien plašāku pielietojumu iegūst arī augstas caurlaidspējas genotipēšanas platformas, kas ḷauj novērtēt g’enētisko daudzveidību lauksaimniecības augos visa genoma mērogā. Pētìjumā mēs novērtējām ğenētisko daudzveidību Latvijas miežu šḳirnēs un tām radniecīgās līnijās, izmantojot DArT markierus, kā arī pētìjām nelīdzsvarotās saistības izplatību Latvijas miežu genomā. Tika novērtēta ǵenētiskā daudzveidība trijos ǵenētiskos lokusos, 206i20_T7, ABC15612 and 538P8, kas atrodas miežu miltrasas izturības lokusa Mla tuvumā. Mla lokuss satur vairākus radniecīgus slimību izturības gēnu homologus, kuri nodrošina izturību pret noteiktām miltrasas rasēm, taču lokusa sarežǵḡitā evolucionārā vēsture un gēnu augstā homoloğijas pakāpe apgrūtina molekulāro markieru izveidi specifiskiem Mla gēniem. Novērojām statistiski nozīmīgu nelīdzsvaroto saistību starp punktveida mutācijām trijos sekvencētajos lokusos, kas atrodas abās pusēs Mla lokusam. Punktveida mutāciju veidotie haplotipi pārsvarā saskanēja ar publicēto Latvijas miežu šķiņu miltrasas izturības fenotipu, tādējādi šie haplotipi ir uzskatāmi par diagnostiskiem miltrasas izturības gēniem un nākotnē var noderēt specifisku molekulāro markieru izveidei. 